\title{
Demografik Değişim ve İşsizlik Oranı
}

\author{
Mustafa NAL ${ }^{1}$ \\ $\ddot{O} z$
}

Türkiye'de işgücü hızlı bir demografik dönüşüm sürecinden geçmektedir. İşgücü içerisinde gençlerin payı azalmakta ve kadınların payı yükselmektedir. Bu çalısmada, bu demografik değişimin (genel) işsizlik oranı üzerine etkisi araştırılmıştır. Böyle bir etkinin varlığı işgücü alt grupları arasındaki işsizlik oranı farklılıklarının sürekli olmasına bağlıdır. Bu nedenle çalışmada öncelikli olarak işgücü alt gruplarında işsizlik oranı farklılıklarına neden olan faktörler ve bu faktörlerin kalıcı olup olmadığı araştırılmıştır. Çalışmada elde edilen bulgulara göre, işgücü alt gruplarında iş arama süresi açısından kalıcı fakat küçük farklılıklar bulunmaktadır. Alt gruplar arasında temel farklılığın işsiz stokuna giriş akımlarından kaynaklandığı bulgusuna ulaşılmıştır. Buna göre işgücünün bazı alt grupları işsiz stokuna daha sık aralıklarla katılmakta ve bu nedenle iş yaşamının toplamda daha uzun süresini işsiz olarak geçirmektedir. Bu bulgular veri iken işgücünün demografik alt gruplarında pay değişimi işsizlik oranı üzerinde bir etkiye sahiptir. Bu etki pay vektörü ve alt grup özgün işsizlik oranı vektörü ile analiz edilmiştir. Analiz sonuçlarına göre orta yaş grubunun payının artışı ise işsizlik oranını azaltma yönünde, kadınların işgücü içerisindeki paylarının artışı genel işsizlik oranını yükseltme yönünde baskı yapmaktadır. Bu sonuç kentsel kadın işgücünün artması durumunda geçerli olmaktadır.

Anabtar Kelimeler: Demografik Değişim, Alt Grup İşsizlik Oranı Farklılıkları, Pay Değişim Etkisi, Özgün İşsizlik Değişimi Etkisi

\section{Demographic Change and Unemployment}

\section{Abstract}

Turkish labor force is undergoing a rapid process of demographic transition. In the labor force, the share of young people is decreasing and the share of women increases. In this study, the effect of this demographic change on the (overall) unemployment rate was investigated. The existence of such an impact depends on the fact that the unemployment rate differentials between sub-groups of labor are continuous. For that reason, the factors which cause unemployment rate differentials in the labor sub-groups and the persistence of these factors were investigated. According to the findings obtained in the study, there are permanent but small differences in labor subgroups in terms of job search time. It was found that the main difference between the subgroups was caused by the inflows of the unemployed stock. Accordingly, some sub-groups of the labor force participate more frequently in the unemployed stock and therefore spend a longer period of work life as unemployed. These findings are given, the shift share in the demographic sub-groups of the labor force has an effect on the (overall) unemployment rate. This effect was analyzed by the share vector and sub-group specific unemployment rate vector. According to the results of the analysis, the increase in the share of the middle age group reduce the unemployment rate and the increase in the share of women in the labor force increase the unemployment rate. This result is valid in case of increase in urban female labor force.

Key Words: Demographic Change, Sub-Group Unemployment Rate Differentials, Shift Share Effect, Effect of SubGroup Specific Unemployment Rate.

\section{Atıf İçin / Please Cite As:}

Nal, M. (2020). Demografik değişim ve işsizlik oranı. Manas Sosyal Araștırmalar Dergisi, 9(1), 76-89. 


\section{Giriş}

Türkiye'de işgücü son 20 yllda önemli bir demografik değişim süreci geçirmiştir. Nüfus artış oranının azalması nedeniyle işgücü içerisinde gençlerin payı azalmış ve kentleşmenin etkisiyle kadın işgücünün payı yükselmiştir. Bu süreç, 2010'lu yıllarda görünür hale gelmiş ve nüfusun yaşlanması ve çalışan kadınların sorunları siyasetçilerin söylemlerinde daha sık yer almaya başlamıştır. Bu dönemde akademik yazının da demografi üzerine ilgisi artmış ve çok sayıda çalışma yapılmışıı. Bu yazının büyük bir kısmı dezavantajı gruplar olan gençler ve kadınların çeşitli yönlerden analizi üzerine gelişmiştir. Ortaya çıkan yazında genellikle yaşanan yüksek işsizlik oranı ve kötü emek piyasası performansı veri alınmış ve bu durumun demografik gruplar üzerine olumsuz etkileri analiz edilmiştir. Demografik olarak dinamik toplumlarda nedensellik ilișkisi ters yönden de incelenebilir. Örneğin yapısal olarak yüksek işsizlik oranına sahip demografik alt grupların işgücü içerisindeki payının yükselmesi/düşmesi veya işgücü payı yüksek bir demografik alt grupta işsizlik oranının azalması/artması genel işsizlik oranı üzerinde mekanik bir etkiye sahiptir. Demografik değişmenin bu tarz etkilerinin incelenmesi yurtdışı yazında eski bir gelenektir. Batı toplumlarının demografik açıdan dinamik olduğu 1970 ve $80^{\prime}$ li yıllarda bu alanda çalışmalar hızlanmış ve daha sonra dinamizmin azalması ile günümüzde bu alana ilgi de azalmıştır.

Bu çalışma, Türkiye'de işgücü alt gruplarında işsizlik ve demografik değişim üzerine ampirik bir araştırma içermektedir. Neden işgücü (yaş ve cinsiyet açısından) alt gruplarında işsizlik oranları farklıdır ve bu farklılıklar zaman içerisinde değișebilir mi? sorusu çalışmanın araştırdığı sorulardan birini oluşturmaktadır. Emek piyasasında, işsiz sayısı bir stok değişken olarak ele alınırsa, bu stokun büyüklüğü iki faktör tarafindan belirlenmektedir; dönem içerisinde stoktan çıkanlar ve stoka katılanlar/girenler. Bu çalışmada, bir demografik grubun karakteristik özelliklerinin bu akımlarda ortaya çıktığ1 varsayılacaktır. Örneğin işgücüne yeni katılımlar 15-19 yaş grubunda diğer yaş gruplarına göre karakteristik olarak daha yüksektir. Benzer şekilde son 10 yıllık dönemde kadınlarda yeni katılım erkeklere göre daha yüksektir. Yukarıdaki ilk örnekte olduğu gibi bazı demografik gruplarda karakteristik özellikler mantıksal olarak tahmin edilebilir nitelikte iken bazı karakteristik özelliklerin istatistiksel olarak araştırılması gerekmektedir. Çalışmamızda (stoka) giriş akımları ve (stoktan) çıkış akımları için beş adet gösterge hesaplanarak grupların karakteristik özellikleri analiz edilecektir.

Bu çalışmada araştırılan diğer konu ise birinci konunun bir uzantısı olarak, (demografik gruplar arasında ortalama işsizlik oranı farklıllğı veri iken) demografik değişim sürecinin işsizlik oranı üzerine etkisidir. Genel işsizlik oranı - özdeşlik olarak - alt grup işsizlik oranlarının ağırlıklı bir ortalamasıdır. Burada ağırlıklar, alt grupların toplam işgücü içerisindeki payları ile ölçülmektedir. Demografik değişme bu payların değişmesi yoluyla genel işsizlik oranını etkilemektedir. İktisat yazınında demografinin bu tarz etkisine ilk defa Perry (1970) tarafindan dikkat çekilmiştir. Bu öncü çalışmada G.Perry'nin temel önermesi şöyledir; ekonomi politikalarının tasarlanma sürecinde ekonominin konjonktürel durumunu değerlendirmek için kullanılan en önemli araç değişkenlerden biri işsizlik oranıdır. Buna karşın, demografik olarak dinamik işgücüne sahip ekonomilerde genel işsizlik oranının bu amaçla kullanılması hatalı değerlendirmeye neden olabilir. Örneğin demografik değişme yüksek işsizlik oranına sahip alt grubun işgücü içerisindeki payının artışı yönünde ise ekonominin konjonktüründen bağımsız olarak işsizlik oranı artmaktır. Böyle bir durumda bugün yaşanan daha yüksek işsizlik oranı aslında geçmişteki daha düşük bir işsizlik oranından (NAIRU konsepti içerisinde) daha enflasyonisttir.

Bu argümanlar ile Perry (1970), ABD ekonomisinde 1951-1969 dönemi için işgücünün yaş kompozisyonunda genç işçiler lehine görülen değişmeye odaklanarak; alt grup işgücü payları, bu grupların verimlilikleri ve çalışma sürelerini içeren ağıllıklandırılımış işsizlik oranı serisi hesaplamıştır. Daha sonra bu alanda gelişen yazında bu seri, Perry ağılıklandırılmış işsizlik oranı veya demokrafik ağırlıklandırılmıs işsizlik oranı olarak adlandırılmıştır.

G.Perry'nin analizi tam bir emek piyasası modelinden ziyade, demografik bir olgunun bir kontrol değişkeni olarak kullanılmasını içermektedir. Değişsenin anlamlıllğı demografik dinamizmin varllğı ile ilişkilidir. Nitekim, ABD ekonomisinde işgücünde genç işçilerin payının azaldığı 80 sonrası dönemde bu alandaki uygulamalı çalışmalar tekrar artış göstermiştir. Sonraki dönemlerde pay değişimi analizleri, eyalet, endüstri, bölge, $1 \mathrm{rk}$ vb. açılardan devam etse de cinsiyet ve yaş açısından değerlendirme şekli popülaritesini yitirmiştir.

Çalışma üç bölümden oluşmaktadır. Birinci bölüm bu alanda daha önce yapılmış çalışmalar ve yurtiçi yazında işgücü üzerine yapılan çalışmalar yer almaktadır. İkinci bölümde işgücü alt gruplarında (yaş ve 
cinsiyet açısında) işsizlik oranı farkl11ıklarına neden olan faktörler araştırılmıştır. Üçüncü bölümde demografik analiz için Shimer (1998) çalş̧masına dayanan bir model oluşturulmuş ve Türkiye emek piyasasında demografik değişimin genel işsizlik oranı üzerine etkisi hesaplanmıştır. Sonuç bölümünde ise ikinci ve üçüncü bölümde elde edilen bulgular bir bütün halinde değerlendirilmiştir.

\section{Literatür Taraması}

Demografik kompozisyonunun emek piyasas1 üzerine etkisi ampirik iktisat yazınında eski bir gelenektir ve Batı ekonomilerinin demografik açıdan dinamik olduğu dönemlerde popülerlik kazanmıştır. İkinci dünya savaşının devamında doğum oranlarının artışı (bebek patlaması) nedeniyle, 60’lı ve 70 li yıllarda işgücü içerisinde genç işçilerin payının artışı böyle bir dönemdir. Perry (1970) öncü çalışmasında demografik değişimin NAIRU'da yaratacağı etkiler üzerine bir tartışma alanı başlatmıştır. G.Perry'e göre ekonomik istikrar politikalarının tasarlanmasında temel gösterge değişkenlerden biri olan işsizlik oranı, demografinin değişmesi durumunda bu özelliğini kaybetmektedir. Bunun nedeni işgücü alt gruplarında verimlilik düzeylerinin farklı olmasıdır. Toplumun farklı demografik kompozisyonları için istihdam düzeyleri aynı olsa bile üretim düzeyleri birbirlerinden farklıdır. Bu nedenle, standart işsizlik oranı ölçümü demografik kompozisyonun bir durumunda enflasyonist iken diğer bir durumda deflasyonist olabilir. Bu hatalı belirlemenin temel nedeni standart hesaplamanın tüm bireyleri eşit olarak değerlendirmesidir. İşsiz olan kişilerin istihdam edildiklerinde üretime yaptıkları katkıdaki farkllıkları dikkate alan bir hesaplama farklı dönemlerde emek piyasasının durumunu (market tightness) karşılaştırmada daha iyi bir yöntemdir. Bu argümanlar ile Perry (1970) işgücü alt gruplarının verimliliklerini ve çalışma sürelerini kullanarak ağırlıklandırılmış bir işsizlik oranı hesaplamıştır. Standart ölçüme göre işsizlik oranı 1960'larda 1950'lere göre daha yüksek olmasına rağmen, Perry'nin ölçümüne göre 1960'larda emek piyasası daha enflasyonisttir.

Demografik değişimin etkileri üzerine ampirik çalışmalar sonraki yıllarda da devam etmiştir. Katz ve Krueger (1999), Shimer (1998), Summers (1986), Flaim (1979), Balakrishnan vd. (2015), Barnichon ve Mesters (2017) işgücünün yaş ve/veya cinsiyet kompozisyonundaki değişimin etkileri ve DeBoer ve Seeborg (1984) sanayinin kompozisyonundaki değişmenin etkileri üzerine kanıtlar sunmuşlardır. Fakat bu çalışmalarda Perry (1970)'nin yaklaşımdan farklı bir yöntem izlenmiş ve karşı olgusal (counterfactual) işsizlik oranı serisi hesaplanarak analizler yapılmıştır. Bu analiz alt grup özgün işsizlik oranı etkisi ve mekanik pay değişim etkisi olmak üzere iki şekilde yapılmaktadır. Alt grup özgün işsizlik oranı analizinde, alt grup payları sabit tutularak ve alt grup işsizlik oranında değişime izin verilerek bir işsizlik oranı serisi yaratılmaktadır. Mekanik pay değişim analizinde ise alt grup özgün işsizlik oranı sabit tutularak ve demografik payların değişimine izin verilerek bir işsizlik oranı serisi yaratılmaktadır. Birinci seride eğer alt grup özgün işsizlik oranları işgücü payı yüksek olan gruplarda artmış ise işsizlik oranı artmaktadır. İkinci analizde ise demografik paylar, özgün işsizlik oranının yüksek olduğu alt gruplar lehine büyümüşs ise işsizlik oranı artmaktadır. Her iki durumda da artışın kaynağı konjonktürün durumu ile ilişkisizdir.

Demografinin etkileri üzerine yapılan ampirik çalısmaların genel bulgularına göre bazı demografik değişimlerin etkisi kısa süreli iken bazıları uzun süreli olabilmektedir. Örneğin ABD'de erkek ve kadın işsizlik oranı farklılıkları hızlı bir şekilde azaldığından işgücünün cinsiyet açısından kompozisyonundaki değişmenin etkisi hızlı bir şekilde yok olmuştur. Buna karşın, işgücünün yaş kompozisyonundaki değişmenin işsizlik oranı üzerine daha uzun süreli etkisi olduğu gözlenmiştir. Bunun nedeni genç işçiler ve temel yaş grupları arasında işsizlik oranı farklılı̆̆ının kalıcı olmasıdır. Shimer (1998) ve Katz ve Krueger (1999)'ın bulgularına göre, başlangıç bir nüfus şokunun (bebek patlaması) etkisi ancak nüfus büyüme hızının normale dönmesi ve nüfusun yaş alması ile ortadan kalkabilmektedir.

İşgücü demografisi üzerine yurt içi yazındaki araştırmaların önemli bir kısmı dezavantajl gruplar olan kadın ve genç işçilerin sorunları üzerine yoğunlaşmıştır. Kadınların işgücüne katılma oranının belirleyicileri ve genç işçilerin iş bulma sorunları bu alandaki çalışmaların temel odağını oluşturmaktadır.

Üzerinde fikir birliği sağlanan görüşe (Dayığlu ve Kırdar, 2010; Taymaz, 2010, Özer ve Biçerli, 2003) göre kadınların işgücüne katılımı sürecinin temel belirleyicisi kırdan kente göç ve modernleşme olgusudur. $\mathrm{Bu}$ süreç şöyle gelişmiştir. Cumhuriyetin erken dönemlerinden 2000’li yıllara kadar tarım kesiminin ekonomideki ağırlı̆̆ına paralel olarak nüfusun büyük kısmı kırda yaşamaktadır. Bu yapı içerisinde kadınlar ücretsiz aile işçisi olarak üretime katılmaktadır. 90'lı yılların sonunda hızlanan kentlere göç hareketi ile beraber, kentlere göç eden ailelerdeki kadınlar işgücünden çekilmişlerdir. Bu dönemde kadınların işgücüne katılım oranı $\% 23$ seviyelerine kadar düşmüştür. Yine bu süreçte kent yaşamı ve modernizmin etkisiyle kız çocuklarının eğitimde geçirdiği süre uzamıştır. Kent yaşamı içerisinde yetişen bu yeni neslin yaş alması ve biriktirdikleri beşeri sermaye ile emek piyasasında yer alma arzusu ile kadınların işgücüne katılımını yeniden 
yükselmiştir. 2017 yılında kadınların katılım oranı 2005 yılına göre 10 puan artarak \%33 seviyesine yükselmiştir. Bu süreçte kentlerde kadınların iş bulma sorunları ile beraber kadın işsizlik oranı da yükselmiştir.

Genç işsizliği ise kadın işsizliğine göre daha küresel bir sorundur. Gelişmiş ve gelişmekte olan ülkelerin tamamında 15-24 yaş grubundaki işsizlik oranı temel yaş grubundaki işsizlik oranına göre daha yüksektir. Küresel bir durum olarak ele alınan genç işsizliği sorununun temel nedeninin, bu kişilerin temel yaş grubundaki işgücüne göre daha düşük verimliliğe sahip olduğu düşünülmektedir. Bu nedenle firmalar iş alımlarında daha verimli olan temel yaş grubuna yönelmektedir ve ortalama olarak genç işsizlik oranları daha yüksek olmaktadır (Işık, 2016; Erdayı, 2009).

\section{Türkiye'de İşgücünün Demografisi ve Alt Grup İşsizlik Oranı Üzerine İstatistiksel Olgular}

Türkiye'de yaş ve cinsiyet açısından demografik alt grupların işsizlik oranları arasında önemli farklılıklar bulunmaktadır. İktisadi düşünce, ikame ilişkisi ve esnek ücret mekanizmalarının zaman içerisinde bu farklılığı kapatacağını söylemesine karşın alt gruplar arası işsizlik oranı farklılıkları kapanmamış hatta bazı alt gruplar için artmıştır. Bu durum süreklilik gösteren bazı grup özgün özellikler ile açıklanabilir. Bu alt bölümde bu özellikler dinamik yapı içerisinde araştırılacaktır.

Araştırma Holt ve David (1996) stok-akım çatısı içerisinde yapılacaktır. Bu çatıda işgücü, işgücü-dışı, işsiz, istihdam kavramları stok değişkenler olarak ele alınmaktadır. Stokların büyüklüğü ise akımların büyüklüğü ile belirlenmektedir. Bütüncül bir emek piyasası analizi, bu çatı içerisinde ve bir denge konspeti ile yapılabilir. Bu tarz bir yaklaşım çalışmamızın amacını aşmaktadır. Bunun yerine sadece alt grup işsiz stoku ve bu stoklara giriş ve çıkış akımları için gösterge niteliğinde değişkenler incelenecektir ve durağan durum denge konsepti kullanılmayacaktır. Seçilen değişkenler için Summers (1986) yaklaşımı izlenecektir. Bu yaklaşım emek piyasasında işsizlerin "işsizlik süresi” ve "işsizlik nedeni” ölçütlerinde ayrıştırllmasına dayanmaktadır. Bu açıdan ayrıştırılmış veriler TÜIK İşgücü İstatistikleri veri tabanında yer almaktadır.

İşsizlik süresi verisinden iki gösterge elde edilebilir. Birincisi emek piyasasında bir yıldan uzun süredir iş arayanların toplam işsizlere oranıdır.

$$
\text { i. alt grup uzun dönemli işsizlerin oranı }=\frac{U_{i}^{L}}{L_{i}}
$$

$L_{i}$ ve $U_{i}^{L}$ sırasıyla i. alt grupta işgücü sayısını ve bir yıldan uzun süredir iş bulamayanların sayısını göstermektedir. Bu gösterge, emek piyasasında yapısal işsizliğin bileşenlerden biri olarak sıklıkla kullanılan bir değişkendir (Lazaer ve Spletzer, 2012). Bu oranın yükselmesi, ilgili demografik grup için çıkış akımlarının azalması olarak değerlendirilecektir.

İkinci gösterge kısa dönem işsizler (1 yıldan az süredir iş arayanlar) için ortalama iş arama süresidir. Bu gösterge ağırlıklı ortalamayı gösteren,

$$
\text { i. alt grup ortalama iş arama süresi }=\frac{\sum_{w} w \cdot U_{i w}}{L_{i}^{S}}
$$

formülü ile elde edilecektir. Burada, $L_{i}^{S}$, i. alt grupta bir yıldan az süredir iş arayan kişi sayısını, $w$ iş arama süresi ve $U_{i w}$ ise $i$. alt grupta $w$ süredir iş arayan kişi sayısını göstermektedir. Dinamik stokastik modellerde (Mortensen ve Pissarides, 1999; Mortensen, 2011; Rogerson vd., 2004) ortalama iş arama süresinin azalması işsiz stokundan çıkış akımlarını artıran bir değişmeyi yansıtmaktadır. Bu nedenle bu oranının artışı çıkış akımlarının artması ve iş bulma oranının yükselmesi olarak yorumlanacaktır.

İşsizlik nedeni verisinden işsizler stokuna giriş akımı için 3 gösterge elde edilmiştir. İşsizler stokuna giriş yapan bir iş̧̧i, ya kendi isteği ile işinden ayrılmıştır (job leaver) ya işinden çıarılmışıtır (job loser), ya da emek piyasasına yeni giriş yapmıştır. Birinci ve ikinci akım istihdama, üçüncü akım ise işgücüne oranlanarak analiz yapılacaktır.

$$
\text { i. alt grup işten çıkarılanların oranı }=\frac{U_{i}^{\complement}}{N_{i}}
$$




\section{i. alt grup kendi isteği ile işinden ayrllanlar oranı $=\frac{U_{i}^{k}}{N_{i}}$}

$$
\text { i. alt grup için yeni giriş oranı }=\frac{U_{i}^{y}}{L_{i}}
$$

Denklemlerde $U_{i}^{\varsigma}, U_{i}^{\varsigma}$ ve $U_{i}^{y}$ sırasıyla i. alt grupta işinden çıkarılan, işinden kendi isteği ile ayrılan ve yeni giriş yapan işsiz işçi sayısını, $N_{i}$ ise i. alt grupta istihdam miktarını göstermektedir.

\section{Cinsiyet Gruplarında İşsizlik Oranı Farklılı̆̆}

Türkiye'de kadın ve erkek işsizlik oranı farklılığı 2000'li yıllarda ortaya çıkan bir durumdur. 2005 yılından günümüze kadınların işgücüne katılımı kesintisiz bir şekilde artarken kadın ve erkek işsizlik oranı farkı da yükselmiştir. Aslında, 90’lı yılların başında da kadınların işgücüne katılımı günümüzdeki kadar yüksek olmasına karşın kadın ve erkek işsizlik oranları birbirlerine çok yakındır. Bu iki dönem arasındaki temel değişmeyi açıklayan olgu kentleşme ve modernleşme sürecidir.

90’lı yıllarda kadın işgücünün \% 70'e yakını tarım sektöründe ücretsiz aile işçisi olarak üretime katılmaktadır. Bu kişiler emek piyasasında ticaret sürecine (iş arama süreci ve ücret pazarlıği) katılmadan işgücüne ve üretime katılmaktadır. Bu kişilerin emek piyasasındaki durumu sadece istihdam edilme ve işgücü dışında bulunma olarak değişmektedir. Nitekim bu kişiler kentlere göç ettiklerinde ve kentlerde profesyonel emek piyasaları ile karşılaştıklarından işgücünden çekilmişlerdir. 2000'li yıllarda kadınların işgücüne katılım oranındaki azalma trendi bu olgu ile açıklanmaktadır. Günümüzde ise kentlerde yetişen yeni nesilde kadınlar (tarım-dışı sektörde), iş arama sürecine katılarak ve emek piyasasının diğer katılımcıları ile rekabet ederek üretim sürecinde yer almaktadır. Kadının işgücü içerisindeki bu yeni şekli tarım sektöründeki kadından farklıdır. Yeni durumda kadın istihdam edilmediğinde işgücünden çekilmemekte iş aramakta ve işsiz stokunda yer almaktadır. Bu nedenle kadının, işgücünde ve üretim sürecinde yer alması Türkiye'de yeni bir olgu olmamasına karşın modern emek piyasasında kadın işgücünün artışı yeni bir olgudur.

Tablo 1. Kadin ve Erkek İsgü̈ü için Temel Göstergeler

\begin{tabular}{lrrrrrr}
\hline & $1990-94$ & $1995-99$ & $2000-04$ & $2005-09$ & $2010-14$ & $2014-17$ \\
\hline Kadın İşsizlik Oranı & 8.1 & 7.1 & 8.9 & 11.8 & 11.8 & 13.5 \\
Erkek İşsizlik Oranı & 8.6 & 7.2 & 9.5 & 11.1 & 9.4 & 9.4 \\
Kadın İşücüne Katılım Oranı & 31.8 & 29.9 & 26.3 & 24.2 & 29.4 & 32.5 \\
Erkek İşü̈cüne Katılım Oranı & 79.2 & 76.9 & 71.8 & 70.2 & 71.3 & 72.1 \\
Kadın Kır İşücü Oranı & 0.72 & 0.68 & 0.57 & 0.42 & 0.39 & - \\
\hline
\end{tabular}

Not: TÜIK veri tabannda Issgücü için Kent-Kır ayrrm 2013 yulnna kadar yayınlanmuştrr.

Tablo 1'de kadın ve erkek işgücüne ait bazı göstergelerin zaman içerisindeki değişimi görülmektedir. 90'lı yılların başından günümüze erkek işsizlik oranı ortalama bir puan artarken, kadın işsizlik oranı 5 puanın üzerinde artmıştır. Bu iki uç dönemde de kadınların işgücüne katılım oranı birbirine yakın değerdedir. Buna karşın tabloda kırsal kadın işgücünün azalma ve kadın işsizlik oranlarındaki artış arasındaki korelasyon dikkat çekmektedir. Bir önceki alt bölümde sunulan göstergeler ile bu korelasyonun nedenleri araştırılabilir. 
(a) Uzun Dönem İssizlerin Oranı

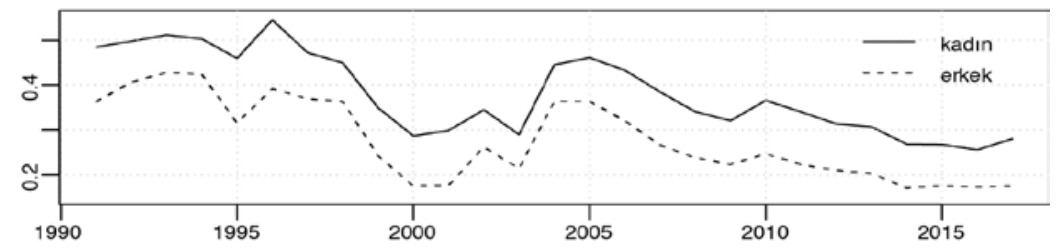

(b) Ortalama is Arama Süresi

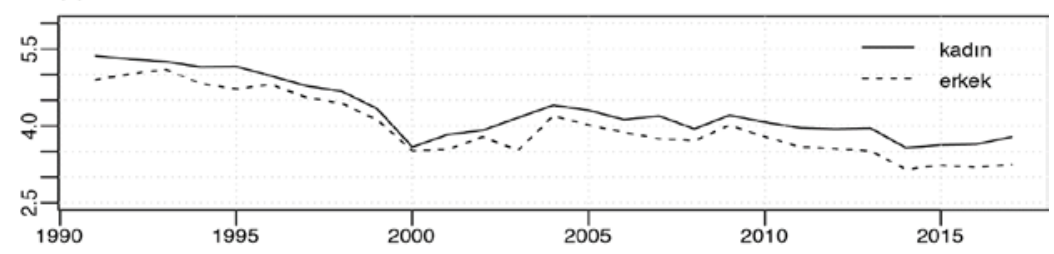

Şekil 1. İssizlikten Çıkıs Akımlar için Göstergeler

İşsiz stokundan çıkış akımı için hesaplanan göstergeler Şekil 1'de görülmektedir. Şeklin a paneline göre hem kadın hem de erkek işçiler arasında uzun dönemli işsizlerin payı zaman içerisinde azalmıştır. $\mathrm{Bu}$ değişme işgücü içerisinde yapısal olarak işsiz olan kesimin azalması anlamına gelmektedir. Şeklin b panelinde ise kısa dönemli işsizler için ortalama iş arama süresinin her iki grup için azaldığı görülmektedir. 2017 yılında kadınların \% 70 ine yakını için, ortalama iş bulma süresi ise yaklaşık 4 aylık bir süredir. Geri kalan \% 30 için ise bir yıldan fazladır. Erkekler de ise \% 80'e yakını için, ortalama iş arama süresi 3,5 ayın altında iken \% 20'si için bir yıldan uzun bir süredir. Her iki göstergede de cinsiyet grupları arasındaki farklılı̆̆n zaman içerisinde azalma eğiliminde olmadığı görülmektedir.

(a) İșten Çıkarılanların İstihdama Oranı

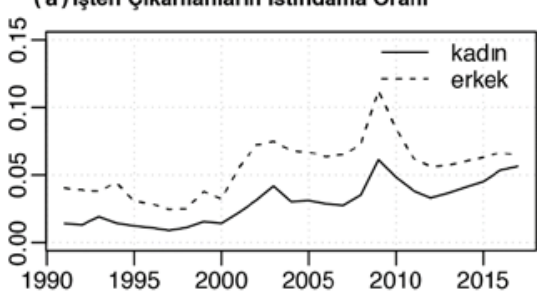

(c) Yeni Katılanların İşgücüne Oranı

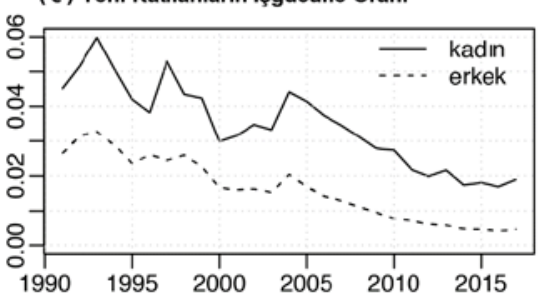

(b) İși Bırakanların İstihdama Oranı

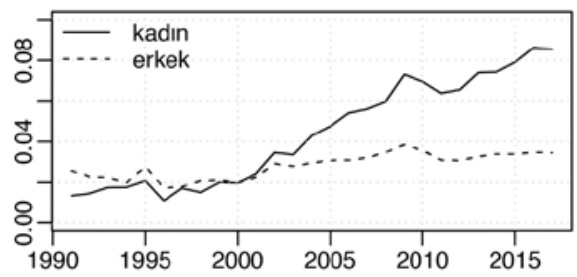

(d) İşten Çıkarılan ve İşi Bırakanların İstihdama Oranı

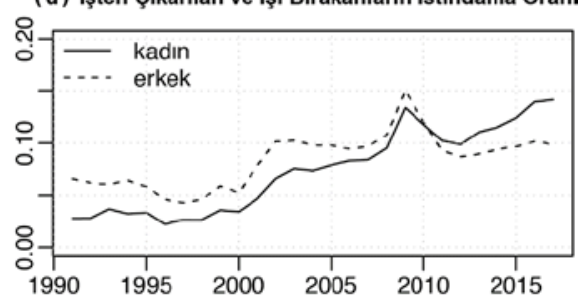

Şekil 2. İsssizlikten Çıkıs Akımlar için Göstergeler

Şekil 2'de işsiz stokuna giriş akımları için hesaplanan göstergeler yer almaktadır. Şeklin a ve b paneli var olan bir istihdam ilişkisinin yok edilmesi ile ilişkili olan akımlardır. d paneli bu iki akımın toplamını ve c paneli ise yeni katılımların oluşturduğu akımları göstermektedir. İlk grafiğe göre işten çıkarılma durumu oransal olarak erkeklerde daha fazla iken zaman içerisinde kadın ve erkek işgücü arasındaki farklılık azalmıştır. İşten kendi isteği ile ayrılma/bırakma oranında ise tersi bir durum söz konusudur. Bu oran hem kadınlarda daha yüksektir hem de zaman içerisinde erkek işgücüne göre hızlı bir şekilde artmıştır. c panelinde ise emek piyasasına işsiz olarak yeni giriş yapanların işgücüne oranı görülmektedir. Kadınlarda hem işgücüne yeni katılımların yüksek olması hem de işgücünün küçük olması nedeniyle yeni giriş oranı erkeklere göre daha fazladır. Fakat fark zaman içerisinde azalmışır.

Cinsiyet açısından ayrıştırılmış verilerde işsiz stokuna giriş ve işsiz stokundan çıkış akımlarına bakıldığında; ortalama olarak çıkış akımları kadınlarda erkeklere göre daha düşük ve giriş akımları bir gösterge dışında kadınlarda daha yüksektir. 2005 yılından günümüze kadın işgücü, katılım oranının artması 
nedeniyle (erkeklere göre) hızlı bir şekilde büyümüştür. Fakat çıkış akımlarını belirleyen göstergelere göre kadınlar daha uzun süre iş arayarak bir işe yerleşebilmektedir. Bu durum kadınlarda işsizlik oranının yüksek olmasının nedenlerinden sadece birini olușturmaktadır. Diğer önemli bulgu, kadınların bir istihdam ilişkisini kendi istekleri ile sonlandırmaya daha yatkın olmalıdır. Şekil 2-d grafiğinde işten çıkarılma ve işi bırakma oranları toplam olarak verilmiştir. 2010 yılından sonra toplam oran kadınlarda erkeklere göre daha yüksektir. Bu sonuca göre kadınlar erkeklere göre daha sık işsiz stokuna giriş yapmakta ve bu nedenle iş yaşamı boyunca ortalama olarak daha uzun bir süreyi işsiz stokunda geçirmektedir.

İş arama, işten çıkarılma ve işten ayrılma durumları modern emek piyasasının unsurlarıdır. Tarımda ücretsiz aile işçisi olarak işgücüne katılan kadınlar bu deneyimler ile karşı karşıya kalmamaktadır. Şekil 2-d panelinde kadınlarda işten çıkarılanlar ve işi kendi isteği bırakanların toplamının 2000 yılından sonra hızlı bir şekilde arttığ görülmektedir. Tablo 1'de ise toplam kadın işgücü içerisinde kırsal(kentsel) kadın işgücünün 2000 yılından sonra hızla azaldığı(arttığı) görülmektedir. İki gösterge arasındaki bu beraber hareket, işten herhangi bir nedenle ayrilma olayının kentsel kadın işgücünün karakteristik bir özelliği olduğunu göstermektedir. Toplam kadın işgücü içerisinde kentsel kadınların oranı arttıkça işten çıkarılan ve işi bırakan oranları yükselmiştir. Özellikle işi bırakanlar oranında bu durum daha belirgin olarak görülmektedir.

\section{Yaş Gruplarında İşsizlik Oranı Farklılıkları}

Demografik analizin diğer önemli unsuru işgücünün yaş kompozisyonudur. Yaş kompozisyonu nüfus artış hızı ile yakından ilişkili bir değişkendir ve artış hızının yavaşlaması işgücünün ortalama yaşının artmasına neden olmaktadır. Tarihsel deneyimler modernleşen toplumlarda nüfus artışı hızının yavaşladığını göstermektedir. Türkiye'de modernleşme sürecinden geçerken nüfus artış hız1 yavaşlamış ve 2000 'li yıllarda genç nüfusun azalması artık görünür ve tartışılır hale gelmiştir. Örneğin 2000 yılında işgücü içerisinde $15-24$ ve $25-34$ yaş gruplarının payı sırasıyla $\% 23$ ve $\% 31$ iken 2017 yılında sırasıyla \%16 ve $\% 27$ 'ye düşmüştür.

Tablo 2'de ise yaş gruplarının yıllara göre işsizlik oranı görülmektedir. İssizilik oranının yaş grupları arasındaki dağılımında genel bir şablon tüm ylllarda değişmeden sürmektedir.

Tablo 2. Kadin ve Erkek İsgü̈ü için Temel Göstergeler

\begin{tabular}{llllllllllll}
\hline & $\mathbf{1 5 - 1 9}$ & $\mathbf{2 0 - 2 4}$ & $\mathbf{2 5 - 2 9}$ & $\mathbf{3 0 - 3 4}$ & $\mathbf{3 5 - 3 9}$ & $\mathbf{4 0 - 4 4}$ & $\mathbf{4 5 - 4 9}$ & $\mathbf{5 0 - 5 4}$ & $\mathbf{5 5 - 5 9}$ & $\mathbf{6 0 - 6 4}$ & $\mathbf{6 5 +}$ \\
\hline $\mathbf{2 0 0 0 - 2 0 0 4}$ & 15.5 & 19.4 & 11.1 & 7.7 & 6.7 & 5.8 & 5.5 & 5.2 & 3.7 & 2.1 & 0.8 \\
$\mathbf{2 0 0 5 - 2 0 0 9}$ & 19.7 & 21.7 & 13.9 & 9.8 & 8.4 & 7.7 & 7.5 & 7.2 & 5.7 & 3.3 & 1 \\
$\mathbf{2 0 1 0 - 2 0 1 4}$ & 16.4 & 20.2 & 13.1 & 8.9 & 7.9 & 7.2 & 7.1 & 7.2 & 6.1 & 3.9 & 1.4 \\
$\mathbf{2 0 1 5 - 2 0 1 7}$ & 16.6 & 21.3 & 14.1 & 9.6 & 8.6 & 7.8 & 7.4 & 7.9 & 7.1 & 5.4 & 2.4 \\
\hline
\end{tabular}

Bu şablona göre işsizliğin en yüksek olduğu grup 20-24 yaş grubu ve ikinci sırada 15-19 yaş grubu yer almaktadır. Diğer gruplarda ise ortalama yaş büyüklügü arttıkça işsizlik oranı azalmaktadır. 65 yaş üstü grupta işsizlik oranının düşük olmasının nedeni, bu yaş grubundaki kişilerin istihdam edilmediklerinde işgücünün dışında kalma eğiliminde olmalıdır.

Gruplar arasında işsizlik oranı farklılıkları üzerine daha detaylı bilgi elde etmek için cinsiyet analizindekine benzer şekilde işsiz stokuna giriş ve işsizlik stokundan çıkış göstergelerinin incelenmesi gerekmektedir. Tablo 3'de bu akımlar için göstergeler yer almaktadır.

Tablo 3. Kadın ve Erkeke İsgücü için Temel Göstergeler

\begin{tabular}{|c|c|c|c|c|c|c|c|c|c|c|}
\hline & 15-19 & $20-24$ & $25-34$ & $34-55$ & $55+$ & 15-19 & $20-24$ & $25-34$ & $34-55$ & $55+$ \\
\hline & \multicolumn{5}{|c|}{ Uzun Dönem İşsizlerin Oranı } & \multicolumn{5}{|c|}{ Ortalama İş Arama Süresi } \\
\hline $2000-2004$ & 0.21 & 0.25 & 0.27 & 0.28 & 0.36 & 3.92 & 3.81 & 3.79 & 3.68 & 3.56 \\
\hline 2005-2009 & 0.25 & 0.3 & 0.33 & 0.32 & 0.45 & 3.95 & 3.99 & 3.99 & 3.84 & 4 \\
\hline 2010-2014 & 0.15 & 0.21 & 0.27 & 0.26 & 0.39 & 3.39 & 3.66 & 3.74 & 3.61 & 3.74 \\
\hline 2015-2017 & 0.09 & 0.16 & 0.24 & 0.23 & 0.37 & 2.92 & 3.39 & 3.54 & 3.41 & 3.53 \\
\hline \multirow[t]{2}{*}{ Ortalama } & 0.18 & 0.23 & 0.28 & 0.28 & 0.39 & 3.55 & 3.71 & 3.77 & 3.64 & 3.71 \\
\hline & \multicolumn{5}{|c|}{ İşten Ç1karılanlar Oranı } & \multicolumn{5}{|c|}{ İşi Bırakanlar Oranı } \\
\hline $2000-2004$ & 0.06 & 0.07 & 0.06 & 0.05 & 0.02 & 0.04 & 0.08 & 0.03 & 0.02 & 0.01 \\
\hline 2005-2009 & 0.09 & 0.09 & 0.08 & 0.06 & 0.02 & 0.08 & 0.11 & 0.04 & 0.02 & 0.01 \\
\hline 2010-2014 & 0.08 & 0.08 & 0.06 & 0.05 & 0.03 & 0.07 & 0.12 & 0.04 & 0.03 & 0.02 \\
\hline
\end{tabular}




\begin{tabular}{l|lllll|llllll}
\hline 2015-2017 & 0.08 & 0.1 & 0.07 & 0.06 & 0.03 & 0.08 & 0.13 & 0.05 & 0.03 & 0.03 \\
Ortalama & 0.08 & 0.09 & 0.07 & 0.06 & 0.03 & 0.07 & 0.11 & 0.04 & 0.03 & 0.02 \\
\hline
\end{tabular}

Tabloda göstergelerin hem uzun dönemde zaman içerisindeki eğilimi hem de uzun dönem ortalama değerleri verilmiştir. Üst ana satır işsizlikten çıkış akımları alt ana satır işsizliğe giriş akımları ile ilişkilidir.

Uzun dönemli işsizlik yüksek yaş gruplarında daha yaygın iken kısa dönemli işsizler için ortalama iş bulma süresi tüm yaş gruplarında birbirine yakın değerlerdedir. Tüm yaş gruplarında ve tüm dönemlerde ortalama iş bulma süresi 4 ayı geçmemektedir.

İşsizliğe giriş akımlarını niteleyen göstergelerde ise yaş grupları arasında farklılıklar bulunmaktadır ve ayrıca zaman içerisinde bu farkllılklar daha belirgin hale gelmiştir. Genel şablona göre yaş düzeyi arttıkça bu oranlar azalmaktadir.

Bu alt bölümde elde edilen genel bulgulara göre, Türkiye emek piyasasının cinsiyet ve yaş açısından demografik alt gruplarında süregelen bir işsizlik oranı farkı bulunmaktadır. İş arama sürelerine dayanan ölçümlerde, yaş grupları arasında önemli bir farklılık bulunmuyorken cinsiyet grupları için kadınlar aleyhine farklılık gözlenmiștir. Başka bir ifade ile kadınlar erkeklere göre daha ortalama olarak daha uzun sürede iş bulabilmektedir. İşsizlik nedenine dayanan ölçümlerde ise hem yaş grupları arasında hem de cinsiyet grupları arasında belirgin farklılıklar bulunmaktadır. Kadınlarda erkeklere göre, düşük yaş gruplarında ise yüksek yaş gruplarına göre işsiz stokuna giriş akımları daha yüksektir. Aynı zamanda alt gruplar arasındaki farklılıkların zaman içerisine azalma eğiliminde olmadığı görülmüştür. Buna göre bu farklılıklar grupların karakteristik özellikleridir. Bu nedenle alt gruplar arasındaki işsizlik oranı farklarının önümüzdeki dönemde yüksek kalması muhtemel bir durumdur.

\section{Yöntem}

Ekonomi geneli işsizlik oranı, işgücü paylanı ile ağırlıklandırılmış alt grup işsizlik oranlarının ortalaması ile hesaplanmaktadır. $i$ işgücü alt grubunu, $U$ işsiz sayısını ve $L$ işgücünü, $u$ işsizlik oranını göstermek üzere;

$$
\begin{gathered}
w_{i}=L_{i} / L \\
u=\sum_{i} w_{i} u_{i}
\end{gathered}
$$

Alt gruplar arasındaki işsizlik oranı farkı veri iken, grupların işgücü paylarında değişme mekanik olarak işsizlik oranında değişmeye neden olmaktadır. Ağırlıklar sabit iken grup özgün işsizlik oranlarında değişme de benzer mekanizma ile genel işsizlik oranını değiştirmektedir. Yazında ilk durum pay değişim etkisi ve ikinci durum alt grup özgün işsizlik oranı etkisi olarak adlandırılmaktadır. Bu bölümde, demografik analiz için Shimer (1998) çalışmasına dayanan bir model oluşturulacak ve bu iki etki Türkiye verileri ile araştırılacaktır.

\section{Model}

İsgücü $n$ adet alt gruptan oluşmaktadır ve $i$ alt grupları göstermektedir $(i=1,2, \ldots, n) . t$ döneminde $i$. alt grubun işgücü $L_{t i}$ ve toplam işgücü $L_{t}$ ile gösterilmektedir.

$$
\sum_{i=1}^{n} L_{t i}=L_{t}
$$

$t$ döneminde $i$. alt grubun işgücü payı $p_{t i}$

$$
\begin{gathered}
p_{t i}=\frac{L_{t i}}{L_{t}} \\
\sum_{i=1}^{n} p_{t i}=1
\end{gathered}
$$

şeklindedir. Alt grup işgücü payları dişsaldır ve dönem boyunca değişmemektedir. $\mathbf{p}_{\mathbf{t}} t$ döneminde alt grup işgücü paylarını gösteren n-boyutlu pay vektörünü göstermektedir. 


$$
\mathbf{p}_{\mathbf{t}}=\left(p_{t 1}, p_{t 2}, \ldots, p_{t n}\right)
$$

$\mathbf{P}$ ise $t-(t+k)$ aralığında alt grup işgücü paylarını gösteren $(k+1) \times n$ boyutlu pay matrisidir.

$$
\mathbf{P}=\left[\begin{array}{ccc}
p_{11} & \cdots & p_{1 n} \\
\vdots & \ddots & \vdots \\
p_{(1+k) 1} & \cdots & p_{(t+k) n}
\end{array}\right]
$$

P matrisinin her bir satır vektörü ilgili dönemdeki alt grup paylarını, her bir sütun vektörü ise ilgili alt grubun işgücü payının zaman içerisindeki değişimini göstermektedir.

Emek piyasasında işsizler de işgücüne benzer şekilde alt gruplara ayrrlmaktadır. $u_{t}^{N} t$ döneminde toplam işsizlik oranını, $U_{t i}$ ve $u_{t i}$ ise sırasıyla $t$ döneminde $i$. alt grupta işsiz sayısını ve alt grup işsizlik oranını göstermektedir.

$$
u_{t i}=\frac{U_{t i}}{L_{t i}}
$$

$\mathbf{u}_{\mathbf{t}}, t$ döneminde alt grup işsizlik vektörünü göstermek üzere,

$$
\mathbf{u}_{\mathbf{t}}=\left(u_{t 1}, u_{t 2}, \ldots u_{t n}\right)
$$

şeklinde tanımlanmaktadır. $\mathbf{U}$ ise $t-(t+k)$ aralı̆̆ında alt grup işgücü paylarını gösteren $(k+1) x n$ boyutlu alt grup işsizlik oranı matrisidir. $t=1$ için bu matris

$$
\mathbf{U}=\left[\begin{array}{ccc}
u_{11} & \cdots & u_{1 n} \\
\vdots & \ddots & \vdots \\
u_{(1+k) 1} & \cdots & u_{(1+k) n}
\end{array}\right]
$$

şeklindedir.

$$
\mathbf{P x} \mathbf{U}^{\prime}=\mathbb{U}
$$

$(k+1) x(k+1)$ boyutlu $\mathbb{U}$ matrisi demografik analiz için gerekli bilgiyi sunmaktadır. Matrisin köşegen elemanları gerçekleşen toplam işsizlik oranını göstermektedir. Örneğin $t=1$ için,

$$
\begin{gathered}
u_{1}^{N}=\mathbb{u}_{11}=\mathbf{p}_{1} \times \mathbf{u}_{1}^{\prime} \\
\left(\mathbb{u n}_{11}, \mathbb{u n}_{22}, \ldots \text { 때(k+1)(k+1) }\right)=\left(u_{1}^{N}, u_{2}^{N}, \ldots u_{(k+1)}^{N}\right)
\end{gathered}
$$

$\mathbb{U}$ matrisinin satılları alt grup işgücü payının değişmediği bir durumda ortaya çıacak işsizlik oranını göstermektedir. Örneğin birinci satır; alt grup işgücü payları $t=1$ dönemindeki değerinde sabit tutulup ve alt grup özgün işsizlik oranının gerçekleşen reel değerlerini almasına izin verildiğinde ortaya çıkacak varsayımsal işsizlik oranı serisini göstermektedir. Eğer bu seride işsizlik oranı artıyorsa, alt grup özgün işsizlik oranı değişimi gerçekleşen toplam işsizlik oranı üzerinde artırıcı yönde etkiye sahip olduğu şeklinde yorumlanacaktır.

$\mathbb{U}$ matrisinin sütunları ise, alt grup işsizlik oranlarının sabit kaldığı bir durumda ortaya çıkacak işsizlik oranını göstermektedir. Örneğin birinci sütun; alt grup özgün işsizlik oranları $t=1$ dönemindeki değerinde sabit tutulup ve alt grup paylarının gerçekleşen reel değerlerini almasına izin verildiğinde ortaya çıkacak varsayımsal işsizlik oranı serisini göstermektedir. Eğer bu seride işsizlik oranı artıyorsa, alt grup paylarındaki değişim, gerçekleşen toplam işsizlik oranı üzerinde artırıcı yönde etkiye sahip olduğu şeklinde yorumlanacaktır.

\section{Bulgular}

Türkiye'de işgücü alt gruplarındaki (yaş ve cinsiyet) değişmelerin genel işsizlik oranı üzerinde etkisi $\mathbb{U}$ matrisinin sunduğu yaklaşım ile değerlendirilecektir. Analiz 2005A1-2018A7 dönemini kapsamaktadır ve veriler TÜIKK İşü̈cü İstatistikleri veri tabanından elde edilmiştir. 
NAL

Demografik Değişim ve İssizlik Oranı

Pay değişimi etkisinin analizinde, alt grup özgün işsizlik oranları 2005 ve 2017 y1lı ortalamasında sabit tutulup alt grup işgücü paylarının değişimine izin verilerek iki varsayımsal işsizlik serisi oluşturulmuştur.

Alt grup özgün işsizlik etkisinin analizinde ise iki dönemli bir yaklaşım tercih edilmiştir. Bu tercihin nedeni alt grup işsizlik oranlarının iki tür etkiyi barındırmasından kaynaklanmaktadır. $\mathbf{u}_{\mathbf{t}}$ vektörünün bileşenleri hem ekonominin konjontüründen hem de grup özgün faktörlerin değişiminden etkilenmektedir. Örneğin konjonktürün yükseldiği bir dönemde $\mathbf{u}_{\mathbf{t}}$ vektörünün tüm bileşenleri aynı anda azalabilir. Konjonktürün etkisini en aza indirip grup özgün etkiyi belirginleştirmek için analiz yapılan dönem genel işsizlik oranı ortalamasının aynı olduğu iki döneme ayrılmıştır. Bu dönemler 2005A1-2013A12 dönemi ve 2014A1-2018A7 dönemidir.

Şekil 3’te cinsiyet grupları için 2015 ve 2017 yılları baz alınarak yapılan hesaplamalara göre pay değişim etkileri gösterilmektedir.

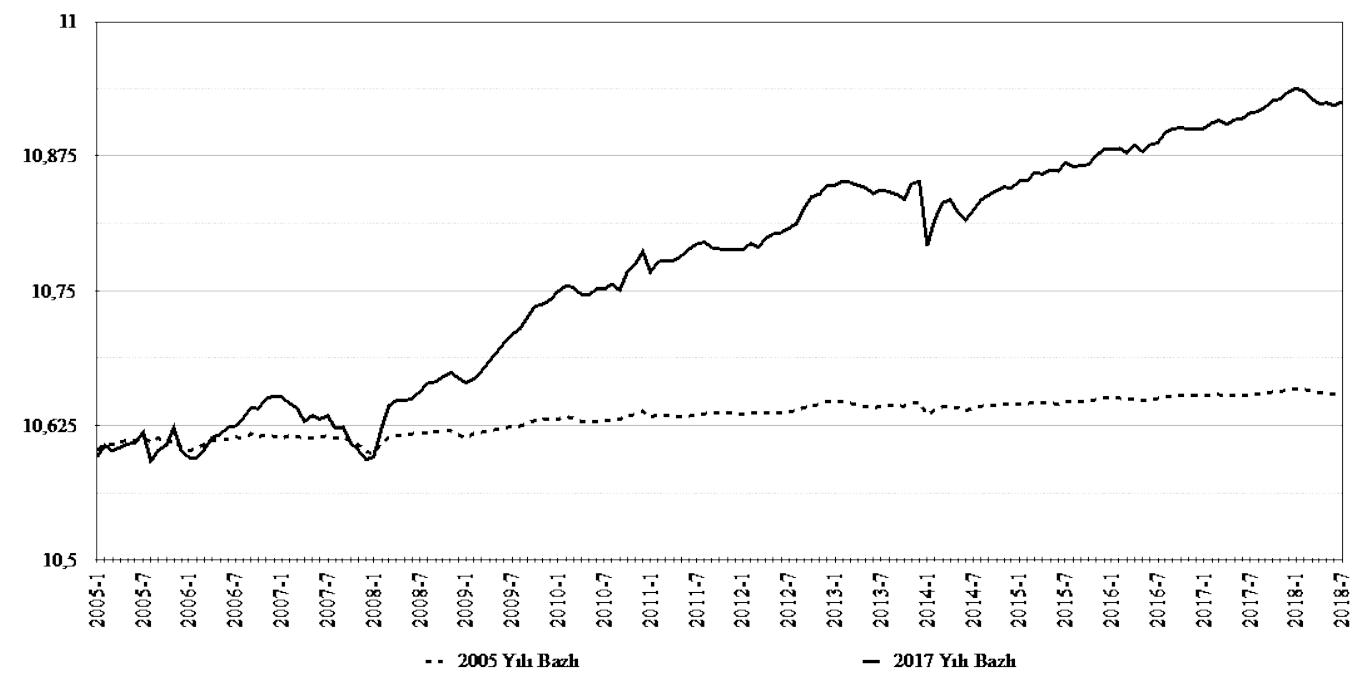

Şekil 3. Cinsiyet Aģısından Alt Grup Pay Değğşim Etkisi

Alt grup işsizlik oranları sabit tutulup işgücü paylarının değişimine izin verildiğinde, varsayımsal işsizlik oranı zaman içerisinde artmıştır. Kadınlarda işsizlik oranı erkeklere göre daha yüksek olduğundan, kadınların işgücü payındaki artış toplam işsizlik oranı üzerinde artırıcı yönde etki de bulunmuştur. 2017 yılında kadın ve erkek işsizlik oranı farkı 2005 yılındakine göre daha yüksek olduğundan 2017 bazlı ölçümde artış daha belirgin olarak görülmektedir. Pay değişiminin işsizlik oranı üzerine etkisi \% \%0,05-\%0,33 aralığında bir değerdir.

Şekil 4'de yaş grupları için 2015 ve 2017 y1lları baz alınarak yapılan hesaplamaya göre pay değişim etkileri gösterilmektedir. 


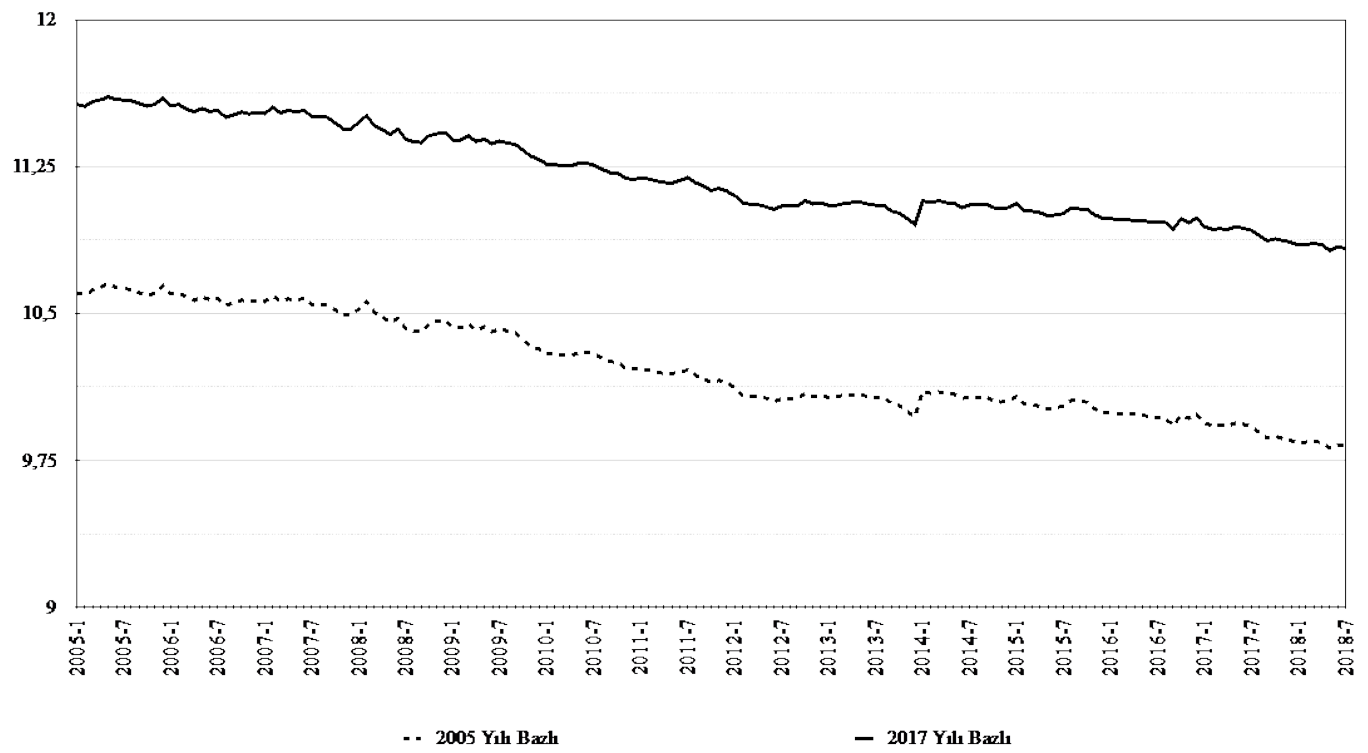

Şekil 4. Yaş Açısından Alt Grup Pay Değğşim Etkisi

Yaş gruplarında işsizlik oranları sabit tutulup işgücü paylarının değişimine izin verildiğinde varsayımsal genel işsizlik oranı zaman içerisinde azalmıştır. Baz yılın 2017 veya 2005 olması genel işsizlik oranının mutlak büyüklüğünü etkilemesine karşın değişimin büyüklüğünü etkilememektedir. 2005-2018 döneminde yaş gruplan açısından demografik değişim grup özgün işsizlik oranının düşük olduğu gruplar lehine gerçekleşmiştir. Yaş grupları açısından pay değişiminin işsizlik oranı üzerine etkisi $\% 0,74-\% 0,79$ arasında bir değerdir.

Grup özgün işsizlik oranı etkisi $\mathbb{U}_{\text {cinsiyet }}$ ve $\mathbb{U}_{\boldsymbol{y a s ̧}}$ de yer alan matrislerde gösterilmektedir. Bu etki yukarıda ifade edilen nedenler iki dönemli olarak analiz edilmiştir.

$$
\begin{gathered}
\mathbb{U}_{\text {cinsiyet }}=\left(\begin{array}{ll}
10,723 & 10,359 \\
10,774 & 10,497
\end{array}\right) \\
\mathbb{U}_{\text {yas }}=\left(\begin{array}{ll}
10,724 & 10,823 \\
10,360 & 10,502
\end{array}\right)
\end{gathered}
$$

Matrislerin birinci satırı işgücü payları birinci dönemde sabit tutularak ve alt grup işsizlik oranları güncel değerlerini aldığında ortaya çıkacak varsayımsal genel işsizlik oranını göstermektedir. İkinci satırlar ise işgücü payları ikinci dönemde sabit tutularak ve alt grup işsizlik oranları güncel değerlerini aldığında ortaya çıkacak varsayımsal genel işsizlik oranını göstermektedir.

$\mathbb{U}_{\text {cinsiyet }}$ matrisine göre grup payları sabit iken grup özgün işsizlik oranlarında birinci dönemden ikinci döneme değişme sonucunda varsayımsal genel işsizlik oranı azalmıștır. Matrisin her iki satııında da değişimin yönü aynıdır. Bu sonuç, Şekil 1 incelendiğinde ilk bakışta tutarsız gibi gözükebilir. Çünkü kadın işsizlik oranı zaman içerisinde artmıştır. $\mathbb{U}_{\text {cinsiyet }}$ matrisini veren $\mathbf{P}$ ve $\mathbf{U}$ matrisi şöyledir;

$$
\mathbf{P}_{\text {cinsiyet }}=\left(\begin{array}{ll}
0,72 & 0,28 \\
0,68 & 0,31
\end{array}\right) \quad \mathbf{U}_{\text {cinsiyet }}=\left(\begin{array}{cc}
10,32 & 11,78 \\
9,28 & 13,16
\end{array}\right)
$$

Kadınlarda işsizlik oranı 1,38 puan artmış, erkeklerde 1,04 puan azalmıştır. Kadın işsizlik oranındaki değişme daha yüksek olsa da, erkek işsizlik oranının ağırlı̆̆ının(işgücü payı) daha büyük olması nedeniyle azalma yönünde eğilim baskın çıkmışır.

$\mathbb{U}_{y a s ̧}$ matrisinde ise grup payları sabit iken grup özgün işsizlik oranlarında birinci dönemden ikinci döneme değişme sonucunda varsayımsal genel işsizlik oranı artmıştır. Yaş grupları analizinde grup sayısı ikiden fazla (11 yaş grubu) olduğundan kısmi etkilerden yola çıkılarak toplam değişim için yorum çıkarılamamaktadır. Fakat toplam değişimden kısmi etkiler için genel bir yorum çıarılabilir. Buna göre, 
Tablo 1'de görüldüğü gibi yaş grupları arasında işsizlik oranlarının zaman içerisinde birbirlerinden farklıdır. Alt grup işgücü payları (ağırlıklar), artış yönünde değişimin baskın çıkmasına neden olmuştur.

\section{Sonuç}

Bu çalışmada Türkiye'de işgücü alt gruplarında özgün işsizlik oranı farklılıklarının nedenleri ve 20052018 dönemi için demografik değişmenin genel işsizlik oranı üzerine etkisi araştırlmıştır. Araştırmadan elde edilen sonuçlara göre, kadınlar erkeklere göre daha uzun sürede iş bulabilmekte ve kadınlar tarafindan yaratılan istihdam erkeklere daha kısa sürede sonlanmaktadır. Yaş grupları açısından ise iş arama süresine dayanan göstergelerde yaş grupları arasındaki farklılıkların düşük olduğu görülmüştür. Bu bulguya göre iş bulma olasılıkları açısından gençler, orta ve ileri yaş grupları arasında önemli bir farklılık bulunmamaktadır. Buna karşın yaratılan istihdam ilişskilerinin düşük yaş gruplarında, yüksek yaş gruplarına göre daha kısa sürede sonlandığı görülmüştür. Türkiye'de kadınlar ve gençlerin yüksek işsizliğe sahip olmasının nedeni olarak, "diğer işgücü gruplarına göre daha zor iş bulabildiği görüşü/önermesi” TÜíK "iş arama süresi”" verisi tarafından kadınlar için kısmen desteklenirken genç işgücü için desteklenmemektedir. TÜİK "işsizlik nedeni” verisinden elde edilen göstergelere göre, bu grupların yüksek işsizlik oranına sahip olmasının temek nedeni istihdam sürelerinin kısa olmasına neden olan faktörlerdir. Buna göre bu gruplar daha sık aralıklarla işsiz stokuna katılmakta ve iş arama sürecine dönmektedir. Bu gruplar içerisinde yer alan temsili bir işçi, iş yaşamı içerisinde ortalama olarak daha uzun süre işsiz stokunda yer almaktadır. Bu nedenle bu gruplarda işsizlik oranı yüksektir.

Çalışmanın ilk bölümünde yer alan sonuçlara göre işgücü alt grupları arasındaki işsizlik oranı farklılıklarına neden olan faktörler zaman içerisinde azalma eğiliminde değildir ve bu grupların karakteristik özellikleri olarak zaman içerisinde süreklilik göstermektedir. Bu nedenle grupların işgücü paylarındaki değişmeler işsizlik oranı üzerinde bir etkiye sahip olması gerekir. Bu etkinin yönü mekanik pay değişim analizi ile araştırılmıştır. Türkiye'de kadın işgücünün payının artısı işsizlik oranını artırma yönünde ve nüfusun yaşlanması işsizlik oranını azalıııı yönde baskı yapmaktadır. Çalışmada, gruplar arası işsizlik oranı farklılıklarının değişimine dayanan özgün işsizlik oranı etkisi de araştırılmışıtı. Cinsiyet açısından gruplarda bu etkinin işsizlik oranını azaltı1 yönde, yaş gruplarında ise artırıcı yönde baskı oluşturduğu sonucuna ulaşılmıştır.

Çalışmada elde edilen bulgular Shimer (1998)'ın ABD ekonomisi için elde ettiği bulgular ile tutarlıdır. Yani Batı ekonomileri gibi Türkiye'de de işgücü kompozisyonu bir dönüşüm sürecinden geçerken, işsizlik oranı üzerinde aşă̆ı/yukar1 yönde bask1 oluşmaktadır. Yaş kompozisyonu açısından Türkiye'deki dönüşümün -Batı ülkelerinde olduğu gibi- orta ve ileri yaş grup paylarının bir dengeye doğru sürekli büyümesi şeklinde olacağı varsayılırsa, önümüzdeki dönemlerde pay değişiminin işsizlik oranı üzerine etkisi aşağ1 yönlü olacaktır.

Türkiye'de kadınların işgücüne katılımı \%33 seviyesindedir ve 2000’li yılların başından beri sürekli artmaktadır. Batı ülkeleri ile kıyaslandığında bu oran düşüktür ve Türkiye’nin henüz yolun başında olduğu ileri sürülebilir. Önümüzdeki dönemlerde kadınların işgücüne katılım oranındaki artı̧̧ devam ederse cinsiyet açısından pay değişim sonuçlarına göre genel işsizlik oranı üzerinde yukarı yönlü bir baskı oluşacaktır.

İşgücünün yaş demografisinde en yüksek işsizlik oranı genç yaş gruplarında görülmektedir. Bu yaş gruplarında işsizlik oranı önümüzdeki dönemlerde artsa bile, bu yaş gruplarının işgücü içerisindeki payları azaldığından etkisi düşük kalacaktır. Yani yaş kompozisyonu açısından özgün işsizlik oranı değişiminin etkisinin yansız olması olasıdır. Buna karşın, kadınlarda hem işsizlik oranı artma eğilimindedir hem de kadınların işgücü payları yükselmektedir. Bu nedenle işgücünün cinsiyet kompozisyonu açısından özgün işsizlik etkisi genel işsizlik oranı üzerine yukarı yönlü baskı yapacağı öngörüsünde bulunulabilir.

Çalışmada ortaya çıkan sonuçlar iki açıdan önemlidir. Birincisi, Türkiye'de demografik değişimin işsizlik oranı üzerine anlamlı bir etkiye sahip olduğu sonucuna ulaşılmışıı ve bu etki ekonominin konjonktüründen bağımsızdır. Bu nedenle Türkiye ekonomisi için NAIRU tahminleri demografi değişkenini içermelidir. İkincisi ise, Türkiye'de genç ve kadın işsizliğini azaltmaya yönelik politikalar, bu grupların iş bulma sorunlarının yanı sıra istihdam süresi sorunlarına da odaklanmalıdır. Özellikle kentsel kadın işgücü için işi kendi isteği ile işi bırakma veya işten çıkarılma oranlarının azalmasını sağlayacak kaliteli istihdam ilişkilileri işsizlik oranı üzerinden kalıcı bir etkiye sahip olacaktır. 
Çalışmada demografik etki analizleri grupların işgücü payları ve işsizlik oranı arasında ilişki olmadığı varsayımı ile oluşturulmuştur. Fakat işgücü payları büyüyen gruplarda işsizlik oranı da artmaktadır. İşgücü paylarının ve işsizlik oranı ile ilişkili olma olasılığı bulunmaktadır. Bu durum analizlerin zayıf noktasını oluşturmaktadır. Bu nedenle çalışmamızda demografik etkilerin genel işsizlik oranı üzerine hangi yönde etkiye sahip olduğu yorumlanmış fakat etkilerin büyüklüğü yorumlanmamıştır. Bu alanda daha kesin yorumlar, işgücü büyüklüğü ve işsizlik oranı arasında var olan potansiyel ilişkiyi de dikkate alan modeller ile araştırllabilecektir.

\section{Kaynakça}

Balakrishnan, R., Dao, M., Sole, J. ve Zook, J. (2015). Recent U.S. labor force dynamics: reversible or not? IMF Working Paper, 1-29.

Barnichon, R. ve Mesters, G. (2017). How tight is the U.S. Labor market? FRBSF Economic Letter, 1-5.

Dayıŏlu, M. ve Kırdar, M. G. (2010). Türkize'de Kadmlarn İsgü̈c̈̈ne Kathlimmda Belirleyici Etkenler ve Eg̈ilimler. Ankara: TC Devlet Planlama Teşkilatı ve Dünya Bankası, 1-75.

DeBoer, L. ve Seeborg, M. (1984). The female-male unemployment differential :effects of changes in industry employment. Monthly Labor Review, November, 8-15.

Erdayı, U. A. (2009). Dünyada genç işsizliği sorununun çözümüne yönelik ulusal politikalar ve türkiye. Çalşsma ve Toplum, 3, 133-162.

Flaim, P. O. (1979). The Effect of demographic changes on the Nation's unemployment rate. Montly Labor Review, 102(3), 13-23.

Holt, C. ve David, M. (1966). The concept of job vacancies in a dynamic theory of the labor market. NBER içinde, The Measurement and Interpretation of Job V acancies (s. 73-110). New York: NBER.

Işı1k, V. (2016). Türkiye'de genç işsizliği ve genç nüfusta atalet. HAK-IŞ Uluslararası Emek ve Toplum Dergisi, 5(11), 131145.

Katz, L. F. ve Krueger, A. B. (1999). The high-pressure US. labor market of the 1990s. BPEA(1), 1-87.

Kızılgöl, Ö. A. (2012). Kadınların işgücüne katılımının belirleyicileri: ekonometrik bir analiz. Doğuş Üniversitesi Dergisi, 13(1), 88-101.

Lazaer, E. P. ve Spletzer, J. R. (2012). The United States labor market: Status quo or a new normal? NBER (w18386), $1-53$.

Mortensen, D. T. (2011). Markets with search friction and the DMP model. American Economic Review, 101, 10731091.

Mortensen, D. T. ve Pissarides, C. A. (1999). Job reallocaiton,employment fluctations and unemployment. J. B. Taylor, ve M. Woodford (Dü) içinde, Handbook of Macroeconomics (Cilt 1B, s. 1071-1228). Elsevier Science B.V.

Özer, M. ve Biçerli, K. (2003). Türkiye'de kadın issgücünün panel veri analizi. Anadolu Üniversitesi Sosyal Bilimler Dergisi, $3(1), 55-86$.

Perry, G. (1970). Changing labor markets and inflation. BPEA(3), 411-448.

Rogerson, R., Shimer, R., ve Wright, R. (2004). Search-theoric models of the labor market: A survey. NBER Working Paper, 1-64.

Shimer, R. (1998). Why is the U.S. unemployment rate so much lower? NBER Macroeconomics Annual, 13, 11-74.

Summers, L. H. (1986). Why is the unemployment rate so very high near full employment. BPEA, 2, 339-396.

Taymaz, E. (2010). Growth, employment, skills and female labor force. Ankara: State Planning of the Republic of Turkey and World Bank,1-44.

Zeren, F., ve Savrul, B. K. (2017). Kadınların işgücüne katılım oranı, ekonomik büyüme, işsizlik oranı ve kentleşme oranı arasındaki saklı koentegrasyon ilişkisininin araştırılması. Yönetim Bilimleri Dergisi, 15(30), 87-103.

\section{EXTENDED ABSTRACT}

In the last 20 years the labor force in Turkey has undergone a significant process of demographic change. Due to the decrease in population growth rate, the share of young people in the labor force decreased and due to urbanization the share of female labor force increased. In terms of the unemployment rate these sub-groups constitute the extreme in the labor market. The measured unemployment rate is a average of the sub-group unemployment rate with weighted the sub-group labor share. Therefore, by definition, change of subgroup share and change of subgroup unemployment rate has a mechanical effect on the measured unemployment rate. In this study, the effect of demographic change on unemployment rate is investigated. Shimer(1998) has defined two types of effects based on demographic groups; genuine change in unemployment (I will refer this as genuine effect) and demographic unemployment change (I will refer this as shift share effect). Genuine change in unemployment is a hypothetical unemployment rate that if demographics had remained unchanged at some initial shares of demographic groups and the disaggregate unemployment rates would have followed the same path that we observed a period. I will refer genuine effect is positive when if the hypothetical unemployment rate increases within this period. Demographic unemployment change is a hypothetical 
unemployment rate that if disaggregate unemployment rates of demographic groups had remained unchanged at some initial level and shares of demographic groups would have followed the same path that we observed a period. I will refer shift share effect is positive when if the hypothetical unemployment rate increases within this period. Critical assumption is that demographics do not affect disaggregate unemployment rates.

The significance of the demographic effects depends on the lack of relationship between the subgroup size and the sub-group unemployment rate. In other words, the relatively high / low unemployment rate should be a characteristic feature of the subgroups. In the study, the characteristics of the groups are investigated with the indicators determining the average job search length and average employment duration. In the analysis of the shift share effect, two hypothetical unemployment rate series have been formed by keeping the sub-group unemployment rates remained at the average of 2005 and 2017 and allowing the change of sub-group labor shares we observed the period. In the analysis of genuine effect, two-period approach was preferred. These periods are the period of 2005M1-2013M12 and 2013M12-2018M7.

According to the results of investigating the indicators, there is no significant difference between age groups in terms of job search time. However, employment duration is shorter in younger age groups. Both the job losers and job leavers are high in younger age groups (15-19 and 20-24). These groups enter into the unemployed stock more frequently and in the unemployment stock there are persons of these groups more than other groups.

In terms of gender, women can find jobs longer time than men. At the same time, employment duration of female is shorter length. Therefore, there are more women in the unemployed stock. In particular, the positive relationship between the increase in the urban female labor force and these characteristics is an important finding in the study. For instance, at 1990s when a large part of the female workforce was in rural areas, in terms of unemployment length and employment length male and female worker were about same. Since recently the average length of job search and duration of employment in the between gender groups and between age groups is different, the unemployment rate distinctness between these groups are not temporary. Therefore, the demographic change has a persistent effect on the unemployment rate.

In the 2005-2017 period, the calculated shift share effect of increasing share of female labor force is positive. In other words, the demographic change in terms of gender had an increasing effect on the unemployment rate. But the demographic change in terms of age had a decreasing effect on the unemployment rate. Preference of the base year as 2005 or 2017 don't change the results. In this period, genuine effect of gender groups had a decreasing effect on overall unemployment rate, in other words it is negative. The reason for the result is that the despite the increase in the female unemployment rate, female workers are low share of the labor force. During this period, a small decrease in the male unemployment rate compensated for the increase in female unemployment rate. In the age groups, genuine effect is calculated positive. The base year preference does not change the results.

The results obtained in the study are important in two respects. First, demographic change in Turkey's labor force has a significant effect on the unemployment rate. Therefore, NAIRU estimates for Turkey should include a demographic variable. Second, policies aimed at reducing youth and female unemployment in Turkey should not only focus on job finding issue but also job duration issue of these groups. 